\title{
Why the Reformation failed in Ireland
}

\author{
Henry A. JefFeries* \\ Arts and Humanities Research Institute, Ulster University
}

\begin{abstract}
A B STR ACT. The Reformation failed comprehensively and absolutely in Ireland before the end of Elizabeth's reign: contemporaries estimated the number of Irish Protestants at between forty and 120 individuals. The debate about that failure has been long running, yet inconclusive. After a short historiographical review, this paper considers a range of factors which may have been pertinent in shaping Irish responses to the Reformation policies of Henry VIII and his Protestant children. It shows that Elizabeth's Reformation in Ireland was stymied by the absence of indigenous support, which meant that religious change was neither propagated by local clergymen nor enforced by the local elites in Irish parishes. It points to the strength and persistence of Catholic resistance to the Reformation in different forms from the very start of Elizabeth's reign in Ireland, contradicting the unsubstantiated notion that passive 'church papistry' was general. Nonetheless, it argues that it was only from the 1580s, when the Catholic church in Ireland was reorganised as a disestablished 'people's church', and infused with the confidence inspired by the Counter-Reformation, can it be stated that the Reformation had failed in Ireland definitively.
\end{abstract}

$\mathrm{T}$ he debate about why the Reformation failed in Ireland has been long running yet inconclusive. ${ }^{1}$ To no small degree that reflected a lack of

* Arts and Humanities Research Institute, Ulster University, henryjefferies@icloud.com

${ }^{1}$ Brendan Bradshaw's efforts to account for the failure of the Reformation by reference to conflicting strategies employed in Elizabeth's reign ('Sword, word and strategy in the Reformation in Ireland' in Hist. Jn., xxi (1978), pp 475-502) prompted Nicholas Canny's rejoinder that the question of failure was mal posée ('Why the Reformation failed in Ireland: une question mal posée?' in Journal of Ecclesiastical History, xxx (1979), pp 423-50). Canny claimed that the Reformation did not fail irrevocably in Ireland until the nineteenth century. Karl Bottigheimer, in turn, argued that the question of failure was bien posée, and declared that the Reformation had certainly failed in Ireland by 1640, if not several decades earlier ('The failure of the Reformation in Ireland: une question bien posée' in Journal of Ecclesiastical History, xxxvi (1985), pp 196-207). Ciaran Brady, 'Conservative subversives: the community of the Pale and the Dublin administration, 1556-86' in P. J. Corish (ed.), Radicals, rebels and establishments: Historical Studies XV (Belfast, 1985), pp 11-32, dated its failure to the 1580s but argued that it was cess and not religion that created the groundswell of opposition. Steven Ellis, 'Economic problems of the church: why the Reformation failed in Ireland' in Journal of Ecclesiastical History, xli (1990), pp 239-65, argued that economic weaknesses in the Irish church prevented it from attracting well-qualified 
empirical research on the subject, particularly for the early years of Elizabeth's Reformation, a problem compounded by impressionistic surveys that created an exaggerated image of Protestant progress. This paper proposes that the fundamental reason why the Reformation failed is that it could neither be enforced nor propagated effectively in Elizabeth's reign in the absence of indigenous support.

Ciaran Brady, citing a seminal paper by Nicholas Canny, claimed that 'for at least a generation, leading Palesmen remained loyal to the [Elizabethan] royal supremacy and to the various doctrines taught under its auspices', and there existed 'a large body of undecided church-papistry surrounded by small pockets of committed Catholicism and Protestantism' as in 'many parts of contemporary England'. 2 He stated that it was the viceroys' 'vastly increased demands' for a form of taxation termed 'cess' that drove the Palesmen into subversion: 'The cess rather than matters of religion or high policy provided a groundswell of discontent'. ${ }^{3}$ During Deputy Perrot's parliament of 1585-6, 'recusancy was appropriated as the country cause, not simply as a cover for other underlying discontents, but as an essential element in the Palesmen's new and solidary sense of identity'.

However, Canny's characterisation of the religious disposition of the Palesmen in the first half of Elizabeth's reign was not as Brady represented it. Canny acknowledged that any local Protestants were few in number: he identified six laymen who conformed to the Elizabethan Church of Ireland (the tiny number is significant), ${ }^{5}$ at least half of whom are now known to have been Catholics before they died. ${ }^{6}$ More significantly, in an often-overlooked observation Canny declared that 'few if any converts to the state religion

clergymen to its parishes and left it dependent on the increasingly antipathetic attitudes of the secular elites. Aidan Clarke, 'Varieties of conformity: the first century of the Church of Ireland' in W. J. Shiels and Diana Woods (eds), The churches, Ireland and the Irish (Oxford, 1989), pp 105-22, offered a wider ranging survey which highlighted the challenges to the established church in the face of popular hostility to its ministry. In recent years the course of the Reformation has been tracked in a number of dioceses or counties: Henry A. Jefferies, Priests and prelates of Armagh in the age of Reformations, 1518-1558 (Dublin, 1997); Mary Ann Lyons, Church and society in County Kildare, c.1480-1547 (Dublin, 2000); Brendan Scott, Religion and Reformation in the Tudor diocese of Meath (Dublin, 2006); James Murray, Enforcing the English Reformation in Ireland: clerical reactions and political conflict in the diocese of Dublin, 1534-1590 (Cambridge, 2009). Henry A. Jefferies, The Irish church and the Tudor Reformations (Dublin, 2010), was intended to track the progress of the Reformation rather than address the question of failure per se.

2 Brady, 'Conservative subversives', pp 12-13. For a comparative study of the Reformation on either side of the Irish Sea, see Henry A. Jefferies, 'Tudor Reformations compared: the Irish Pale and Lancashire' in Christopher Maginn and Gerald Powers (eds), Frontiers, states and identity in early modern Ireland and beyond (Dublin, 2016), pp 71-92.

3 Brady, 'Conservative subversives', pp 16-22.

4 Ibid., p. 29.

5 Canny, 'Why the Reformation failed', p. 431.

6 Jefferies, Irish church, pp 190-1. 
were being won in the Pale during Elizabeth's reign'. ${ }^{7}$ Canny did suggest that it is 'likely that in Dublin, where a determined effort was made to promote "true" religion, many converts were won and retained'. However, that suggestion is contradicted by contemporaries on either side of the denominational divide: the Irish Jesuit, David Wolfe, reported in 1574 that the citizens were 'almost all Catholics', while in 1579 an English Protestant official named Waterhouse noted that the 'whole inhabitants' of Dublin were 'in effect all noted to be obstinate Papists'. ${ }^{10}$ William Fitzwilliam, the viceroy, and Adam Loftus, Elizabethan archbishop of Dublin, reported in a letter of February 1590 that in Dublin 'there are now almost none other [than recusants]. The mayor, perhaps for duty, and some few with him for fashion's sake, will come to the ordinary Sunday sermon but none other man or woman'. ${ }^{11}$ A state paper of December 1600 declared that not more than twenty Irish-born householders in Dublin attended Protestant church services, and of them not more than four would receive communion. ${ }^{12}$ The idea that the Reformation was making real progress in Elizabeth's reign is not supported by substantive evidence.

More recently, in a paper written with James Murray, Brady espoused an entirely different interpretation of why the Reformation failed in Ireland. Together they claimed that Edward VI's Reformation, and particularly the 'abandonment of transubstantiation' and the 'sanctioning of clerical marriage', constituted 'a fundamental challenge to the historical role of the English in Ireland: the mission, that is, to reform Gaelic Ireland according to the conventional norms and uses of the medieval English church'. ${ }^{13}$ They argued that: '[T]he successful establishment of the Reformation in Ireland would ultimately render the English colony's claims to cultural superiority over the Irish irrelevant and anachronistic'. ${ }^{14}$ On the other hand, they stated that 'the resistance provoked by the abortive [religious] changes of the Edwardian regime had been consolidated in the triumphant years of Queen Mary'. ${ }^{15}$ In Elizabeth's reign, they claimed but did not demonstrate that the English clergy succeeded 'in resisting change'. ${ }^{16}$ Brady and Murray highlighted efforts made during Sir Henry Sidney's terms of office to promote the Reformation in Ireland, all of which failed, but, by ascribing every initiative to the viceroy without acknowledging the significance of the queen's 'Instructions' drawn up for him prior to his appointment, they exaggerated Sidney's role. ${ }^{17}$

7 Canny, 'Why the Reformation failed', p. 432.

8 Ibid.

9 Myles Ronan, The Reformation in Ireland under Elizabeth (London, 1930), pp 473-89.

${ }^{10}$ Edward Waterhouse to Walsingham, 31 May 1579 (T.N.A., SP 63/66/66).

11 William Fitzwilliam and Adam Loftus to Burghley and Walsingham, 26 Feb. 1590 (T.N.A., SP 63/150/74).

${ }_{12}$ Paper on the causes of the rebellion in Ireland, [Dec. 1600] (T.N.A., SP 63/207, part 6,126$)$.

13 Ciaran Brady and James Murray, 'Sir Henry Sidney and the Reformation in Ireland' in Elizabethanne Boran and Crawford Gribben (eds), Enforcing the Reformation in Scotland and Ireland, 1550-1700 (Aldershot, 2006), pp 13-39, quotation at pp 28-9.

${ }^{14}$ Ibid., pp 38-9.

15 Ibid., p. 30.

16 Ibid., p. 39.

17 Ibid., pp 18-23. However, see E. P. Shirley, Original letters and papers ... of the Church in Ireland under Edward VI, Mary and Elizabeth (London, 1851), pp 206-9, letter lxxiv; Jefferies, Irish church, pp 155-9. 
For example, they claimed that Sidney wanted to dissolve St Patrick's Cathedral, Dublin, both to neutralise a bastion of Catholicism and defray the cost of the English garrison in Ireland. ${ }^{18}$ In fact, the 'Instructions' had already directed Sidney to dissolve the cathedral and transform it into a university. ${ }^{19}$ Of far greater import, though, is the problem of the central thesis: that the Reformation in Ireland failed because it challenged the 'historic role of the English in Ireland' and threatened their 'claims to cultural superiority over the Irish'. ${ }^{20}$ That, in fact, is Murray's thesis.

For his book on the Reformation in the diocese of Dublin, Murray explicitly eschewed an English-style study for want of evidence. ${ }^{21}$ Instead he presented a thesis that Dublin's clerical elites were committed to a 'Laudabiliter-inspired and intrinsically English version of Catholicism' that was 'decisive in shaping the overall response of the Englishry to the Tudors' religious innovations during the sixteenth century'.22 According to Murray, the doctrinal and liturgical aspects of the Reformation were of 'little concern' to Dublin's clerical elites. ${ }^{23}$ Rather they opposed the Reformation because it threatened their 'historic role in Ireland: the reformation of Gaelic Irish society along conventional canonical lines'. ${ }^{24}$ He claimed that clerical celibacy was the 'litmus test of canonical rectitude ${ }^{25}$ and that Protestantism was 'discredited' by the fact that Protestant clergymen married. ${ }^{26}$ The thesis that the Reformation was rejected in Ireland because of clerical marriage is improbable. Nor is it credible that the identity of the Old English community in Ireland was based primarily on a mission to reform the sexual mores of Gaelic society even though, according to Murray, that mission had failed abjectly over the course of the previous four centuries: he made the exaggerated claim that 'sexual expression was uninhibited' in Gaelic society in the sixteenth century. ${ }^{27}$ Yet the main weakness in the thesis is that it is not based on sufficient tangible evidence. Murray offered no evidence of anyone in Ireland articulating opposition to the Reformation on the basis of such a historic role or mission. Nor did he cite any reference to opposition on such grounds from contemporaries on either side of the religious divide. It is simply incredible that a phenomenon that was supposedly powerful enough to thwart the Reformation in Ireland left no trace on paper. In the absence of evidence, therefore, one must look elsewhere for convincing explanations of why the Reformation failed in Ireland.

The failure of the Reformation in Ireland was not pre-determined by the state of the church or religion on the eve of the Reformation. Nonetheless, one

18 Brady and Murray, 'Sir Henry Sidney', pp 30-1.

19 Shirley, Original letters, pp 208-09, letter lxxiv.

20 Brady and Murray, 'Sir Henry Sidney', pp 28-9, 38-9.

21 Murray, Enforcing the English Reformation, p. 15.

22 Ibid., pp 48-9.

23 Ibid., p. 80.

24 Ibid., pp 56, 80.

25 Ibid., p. 247.

26 Ibid., p. 220.

27 Ibid., pp 35-6. 
cannot understand the tortuous courses of the Tudor Reformations without an appreciation of the strength of Catholic commitment. ${ }^{28}$ Recent work has revealed that the Catholic church in Ireland on the eve of the Reformation provided a system of pastoral care which was not only durable and efficacious, but which was growing stronger. The church in Ireland enjoyed massive lay investment in the building of many new churches, and the re-modelling of many older churches in the decades before the Reformation. ${ }^{29}$ The establishment of the office of churchwarden in many parishes, and the formation of religious confraternities were other manifestations of an increase in lay involvement in and commitment to the church and religion. ${ }^{30}$ The burgeoning of the mendicant orders was simply the most dramatic example of a wider pattern of renewal that swept through the Irish church before the Tudor Reformations. ${ }^{31}$

The general commitment to distinctively Catholic beliefs and practices in Ireland is well-exemplified by a surviving collection of wills from men and women of relatively humble backgrounds which shows their belief in the efficacy of the mass, the value of prayers for the intercession of the Virgin and other saints, as well as the existence of purgatory. ${ }^{32}$ The book of obits and martyrology of Christ Church, Dublin, shows the same commitment to distinctively Catholic doctrines among individuals of higher status and greater wealth. ${ }^{33}$ Chantry chapels, where priests were employed to celebrate masses in perpetuity for the souls of specific deceased individuals and their families, were being founded right up to the moment of Henry VIII's breach with Rome. ${ }^{34}$ Salvador Ryan's work on religious piety has revealed patterns of commitment to Catholic doctrines and beliefs that transcended the cultural divide across Ireland. ${ }^{35}$ That commitment to Catholicism may not have been enough in itself to immunise the people in Ireland to Protestant theology: it certainly proved insufficient in England. Nonetheless, as in England, it ensured that the Reformation involved a real struggle for hearts and souls.

Popular sentiment towards Henry VIII's breach with Rome was initially reflected by the widespread clerical and lay support for the Kildare rebellion of 1534-5. ${ }^{36}$ Murray's statement that 'a Laudabiliter-inspired canonical ethos' made the rebel leader's clerical counsellors promote his rebellion against Henry VIII because 'they believed that the English were there [in Ireland] under papal sanction to reform the Irishry along conventional canonical lines'

28 This case was established by English 'revisionist' historians: Christopher Haigh (ed.), The English Reformation revised (Cambridge, 1987); idem, English Reformations: religion, politics and society under the Tudors (Oxford, 1993); Eamon Duffy, The stripping of the altars: traditional religion in England, 1400-1580 (London, 1992).

29 Jefferies, Irish church, pp 15-22.

30 Ibid., pp 58-64.

31 Colmán Ó Clabaigh, The friars in Ireland, 1224-1540 (Dublin, 2012), pp 53-86.

${ }^{32}$ H. F. Berry (ed.), Register of wills and inventories of the diocese of Dublin in the time of Archbishops Tregury and Walton, 1457-1483 (Dublin, 1898).

${ }^{33}$ John Clarke Crosthwaite (ed.), The book of obits and martyrology of the Cathedral Church of the Holy Trinity, commonly called Christ Church, Dublin (Dublin, 1844).

34 Jefferies, Priests and prelates of Armagh, pp 24-5.

35 Salvador Ryan, 'The devotional landscape of medieval Irish cultural Catholicism inter hibernicos et inter anglicos, c.1200-c.1550' in Oliver P. Rafferty (ed.), Irish Catholic identities (Manchester, 2013), pp 62-74.

${ }^{36}$ Steven Ellis, 'The Kildare rebellion and the early Henrician Reformation' in Hist. Jn., xix (1976), pp 807-30. 
must be dismissed for want of evidence. ${ }^{37}$ Nonetheless, after the rebellion was crushed there was, as Bradshaw observed, a broad acquiescence in Henry's royal supremacy. ${ }^{38}$ The king was acknowledged to be the supreme head of the Church in Ireland by the Irish parliament of $1536-7 .{ }^{39} \mathrm{He}$ abrogated the papacy's authority over much of Ireland. Appeals to the Roman curia for faculties and dispensations were all but ended in the Pale. ${ }^{40}$ More and more bishops owed their appointment, or at least their continuance in office, to the king. The Irish Valor ecclesiasticus reflected Henry VIII's ability to levy taxation on benefices across the English lordship in Ireland. Religious houses were dissolved across the Pale and far beyond. ${ }^{41}$ Relics were despoiled in the dioceses of Dublin and Meath. ${ }^{42}$ Yet, contrary to Murray's claims about resolute opposition offered by Dublin's corporate clerical elites, only one of them, James Humphrey, opposed the changes openly at first, and even he came to terms with them in time. ${ }^{43}$ In any case, with the dissolution of the religious houses in 1538-40 and the suppression of St Patrick's Cathedral, Dublin, in 1547, Dublin's corporate clerical elites were all but eliminated.

There is evidence of antipathy towards the radicalisation of the Reformation under Edward VI. Bishop Staples' first Protestant sermon, delivered in November 1548, provoked a visceral reaction in Meath diocese and even a call for him to be burned as a heretic: 'for he would make us worse than Jews'. ${ }^{44}$ The viceroy reckoned that the response to a subsequent sermon was such that he showed 'no great haste' to repeat the experience. ${ }^{45}$ Of Kilkenny, Bishop John Bale wrote, 'helpers I found none among my prebendaries and clergy, but adversaries a great many'. ${ }^{46}$ A number of Bale's servants were murdered and the bishop himself fled the city for fear of his life. He was convinced that the Edwardian archbishop of Armagh had been murdered by priests of that diocese. ${ }^{47}$ Interestingly, in Edward's reign there were calls by laymen to boycott sermons 'lest they learn to become heretics" 48 and withhold money from the church if it was Protestantised ${ }^{49}$ - portents of Catholic responses to

37 Murray, Enforcing the English Reformation, pp 86-7.

38 Brendan Bradshaw, The Irish constitutional revolution of the sixteenth century (Cambridge, 1979), p. 165.

39 Brendan Bradshaw, 'The opposition to the ecclesiastical legislation in the Irish Reformation parliament' in I.H.S., xvi, no. 63 (Mar. 1969), pp 285-303; Henry A. Jefferies, 'The early Tudor Reformations in the Irish Pale' in Journal of Ecclesiastical History, lii (2001), pp 47-50.

${ }^{40}$ Ellis, 'Economic problems', pp 244-57; Jefferies, Priests and prelates, pp 141-5; idem, 'Early Tudor Reformations', pp 57-8.

${ }^{41}$ Brendan Bradshaw, The dissolution of the religious orders in Ireland under Henry VIII (Cambridge, 1974); Jefferies, 'Early Tudor Reformations', p. 48.

42 Jefferies, Priests and prelates, p. 146.

43 Murray, Enforcing the English Reformation, pp 109-12, 154.

44 Shirley, Original letters, p. 24, letter vii.

45 Ibid., p. 42, letter xvii.

46 'The vocacyon of Iohan Bale, to the bishoprick of Ossorie, in Ireland', ed. Thomas Parke, in Harleian Miscellany, i, (London, 1808), p. 351.

47 Ibid., p. 352.

48 Shirley, Original letters, p. 24, letter vii.

49 Brendan Bradshaw, 'The Edwardian Reformation in Ireland' in Archiv. Hib., xxvi (1976-7), p. 86. 
Elizabeth's Reformation. ${ }^{50}$ Yet the response to Edward VI's Reformation in Ireland was strikingly inchoate.

After delivering a forthright sermon directed against a crown-sponsored Protestant preacher active in Dublin in September 1548, Archbishop George Browne subsequently introduced the first Book of Common Prayer into his diocese and complemented it with a 'book of Reformation' for use throughout Dublin's ecclesiastical province. ${ }^{51}$ The contents of the 'book of Reformation' must remain a matter for speculation but, according to a letter from Deputy Bellingham, it established 'godly and true order' in the church 'grounded upon holy writ; the king's majesty's injunctions being consonant thereunto'. 52 The fact that Browne criticised Archbishop George Dowdall for the continued use of the mass, holy water and Candlemas candles in Armagh diocese suggests that the assault on Catholic practices elsewhere was significant enough. ${ }^{53}$ Dowdall felt obliged to go into exile in 1551 because, he declared, he would 'never be bishop where the holy mass (as he called it) was abolished'. ${ }^{\text {. That is }}$ a very telling indicator that he considered that the survival of Catholicism in Ireland was very far from being assured at that time. As for Dublin's muchvaunted 'corporate clerical elites', only the former treasurer of St Patrick's Cathedral is known to have made any attempt to rouse resistance to the religious changes. ${ }^{55}$ In Kilkenny, Bishop Bale demonstrated in 1553 that passion, energy and imagination could inspire enthusiasm for the 'Word of God' in Ireland, at least according to his own colourful account. Nonetheless, once Mary's proclamation of religious toleration was read in the town, the local clergy "suddenly set up all the altars and images in the cathedral church'. ${ }^{56}$ The Reformation was swept away and Bale left Kilkenny forever. Yet Bale's experiences in Edward's reign, and Dowdall's flight into exile, beg the question of what might have happened had Edward VI lived as long as could reasonably have been expected.

Dowdall was, in fact, reconciled to Rome while in exile and he returned to Armagh in 1553 with Mary's blessing. ${ }^{57}$ He convened a provincial synod soon afterwards which endorsed a series of decrees designed to restore the church to how it had been before Henry's breach with Rome. ${ }^{58}$ Significantly, though, the records of his annual diocesan synods and his next provincial synod give no indication that Protestantism presented any challenges in either Armagh or in Meath, one of its suffragan dioceses. ${ }^{59}$ The same impression is created by the Irish entries in Cardinal Pole's legatine register. ${ }^{60}$ As regards doctrinal deviancy,

${ }^{50}$ Henry A. Jefferies, 'Elizabeth's Reformation in the Irish Pale' in Journal of Ecclesiastical History, lxvi (2015), pp 528-31.

51 Walter Palatyne to Edward Bellingham, 23 Nov. 1548 (T.N.A., SP 61/1/133);

Bradshaw, 'The Edwardian Reformation in Ireland', p. 84.

${ }_{53}$ Shirley, Original letters, p. 30, letter x.

53 Ibid., pp 54-60, letter xxiii.

54 Ibid.

55 Shirley, Original letters, p. 30, letter x; Jefferies, Irish church, p. 91.

56 Bale, 'Vocacyon', p. 454.

57 Jefferies, Priests and prelates of Armagh, p. 105.

58 Ibid., pp 166-7; idem, Irish church, pp 105-7.

59 Jefferies, Priests and prelates, pp 167-8.

60 The correspondence of Reginald Pole, 1500-1558, ed. T. F. Mayer (4 vols, Aldershot, 2002-2008), passim; for Irish entries see: Jefferies, Irish church, pp 111-15. 
John Haklott, a layman in Dublin bearing a surname that was unusual in Ireland, was the only supplicant for a legatine absolution for heresy. ${ }^{61}$

James Murray has presented 'the triumphant years of Queen Mary' as a watershed in the course of the Reformation in Ireland.$^{62}$ Central to his thesis is a supposed Laudabiliter-inspired 'Dowdall programme' for Dublin diocese. ${ }^{63}$ The main problem with that thesis is the absence of evidence to substantiate it: the 'programme' was concocted by crediting Dowdall with every ecclesiastical initiative in Mary's reign, including those of the queen herself. ${ }^{64}$ It was Mary, with belated support from Pole, who shaped the Catholic restoration in Ireland. The overall impression is one of conservative Catholic renovation, not transformation. ${ }^{65}$ The endorsement of the Elizabethan religious settlement by the Irish parliament in January 1560 shows that the Counter-Reformation was not yet established in Ireland at that date. ${ }^{66}$

\section{III}

The popular response to the Elizabethan Book of Common Prayer was reflected in general non-attendance at Protestant services from the start, and by the disruptive behaviour of many of those compelled to attend against their will. $^{67}$ In 1563 a fine seems to have been instituted on the heads of any households in Dublin who refused to attend the Elizabethan service on Sundays. ${ }^{68}$ Yet the viceroy, Sussex, complained that 'our religion is so abused as the Papists rejoice ... [People] come to divine service as to a May game'. ${ }^{69}$ He observed that the dissent was so great that no commission would be sufficient to tackle it and he proposed that parliamentary legislation was needed to address it. The queen's commissioners confirmed in March 1564 that it was 'hard to persuade willingness to hear the truth soberly taught'. Elizabeth authorised the establishment of the Irish Ecclesiastical High Commission in October 1564 specifically to tackle both those who 'obstinately absent themselves from church and divine service as by law established' and those responsible for 'any disturbance or misbehaviour committed or perpetrated in any church or chapel, or against divine service'. ${ }^{71}$

In 1565 Adam Loftus, the Elizabethan archbishop of Armagh and primate of all Ireland, surveyed the parishes of the Pale on behalf of the Irish Ecclesiastical High Commission and found that, 'by their own confessions',

61 Correspondence of Reginald Pole, ed. Mayer, iii (2007), pp 204-5, no. 1445.

62 Brady and Murray, 'Sir Henry Sidney', p. 30.

63 Murray, Enforcing the English Reformation, pp 215-53.

${ }^{64}$ For this discussion in detail and a refutation see: Jefferies, Irish church, chapter 6.

65 Henry A. Jefferies, 'The Marian Restoration in Ireland' in British Catholic History, xxxiii, no. 1 (May 2016), pp 12-31.

66 Jefferies, 'The Irish parliament of 1560: the Anglican reforms authorised' in I.H.S., xxvi, no. 102 (Nov. 1988), pp 139-41.

${ }^{67}$ Jefferies, Irish church, pp 139-42.

68 'The annals of Dudley Loftus', s.a. 1563 (Marsh's Library, Dublin, MS Z 4/2/7).

69 Shirley, Original letters, p. 117, letter xliv.

${ }^{70}$ Ibid., p. 140, letter liv.

71 James Morin (ed.), Calendar of the patent and close rolls of chancery in Ireland of the reigns of Henry VIII, Edward VI, Mary, and Elizabeth, vol. 1 (Dublin, 1861), pp 489-90. 
the 'greatest part' of the nobility and other landholders of the Pale had 'continually' frequented the mass and other Catholic services, while 'very few of them' had ever attended a Protestant service or received communion according to the rites of the Book of Common Prayer. ${ }^{72}$ Loftus explained to the queen that the scale of non-conformity was such, particularly among the nobility and leading gentlemen who 'condemn your majesty's most godly laws and proceedings more manifestly than the rest', that 'we shall never be able to correct them by the ordinary course of the statute' ${ }^{73}$ That general manifestation of recusancy avant la lettre had no parallel in contemporary England or Wales. It directly contradicts the notion that 'church-papistry' was prevalent across the Pale.

Those entrusted with promoting Elizabeth's Reformation in Ireland complained repeatedly in the 1560 s that their efforts were thwarted by 'sturdy and proud Papists', 74 'sworn enemies of the truth, 75 'boasting Mass men'. ${ }^{76}$ Deputy Sidney wrote in April 1566 of Catholic convictions being 'leavened and inveterated in the people's hearts'. ${ }^{77}$ In May 1577, Bishop Brady wrote to Sidney that, 'I find great boldness generally, as well by word as action, against the received religion'. He reckoned that the people were growing more defiant 'in matters of papistry and lewd superstition' ${ }^{78}$ In July 1580 Lord Justice Pelham wrote of, 'A settled hatred and a general contrariety in religion settled, saving in some few whose love to her majesty, favour of the court, or English education, or office or reputation here holds in all appearance of conformity with us'. ${ }^{79}$ The continuing strength of Catholic commitment from the start of Elizabeth's reign in Ireland was clearly a significant factor retarding the progress of the Reformation in Ireland.

A major reason why the Reformation failed in Ireland was that it could not be enforced effectively on the ground in the face of general hostility. Two of the first three bishops to be tendered the oath of supremacy after the 1560 parliament, William Walsh of Meath and Thomas Leverous of Kildare, refused to subscribe and were removed from office. ${ }^{80}$ Christopher Bodkin, archbishop of Tuam, though he subscribed to the oath, continued to celebrate the mass in his cathedral and administered his diocese with the endorsement of the papal commissary to Ireland, David Wolfe S.J. ${ }^{81}$ The attempt to impose the oath of supremacy on the Irish clergy encountered so much opposition in Dublin that it was quickly abandoned lest the church be left bereft of clergy. ${ }^{82}$

72 Adam Loftus to Queen Elizabeth, 17 May 1565 (T.N.A., SP 63/10/42); Shirley, Original letters, pp 195-6, letter lxx.

73 Shirley, Original letters, p. 196, letter 1xx.

${ }^{75}$ Ibid., p. 205, letter 1xxiii.

75 Ibid., p. 135, letter liii.

${ }^{76}$ Ibid., p. 140, letter liv.

77 Ibid., p. 234, letter lxxxii.

78 Hugh Brady to Henry Sidney, 12 May 1577 (T.N.A., SP 63/58/16).

79 Lord Justice Pelham to Walsingham, 29 July 1580 (T.N.A., SP 63/74/75).

80 Jefferies, Irish church, p. 126.

81 Ibid., pp 146-7.

${ }^{82}$ Ibid., pp 128-9. 
When an attempt was made to impose the oath on local government officials in the Pale in 1560 only one town official and three justices of the peace were recorded as having subscribed to it in County Kildare. No record survives to show if any official elsewhere subscribed in 1560. The first mayor of Dublin known to have been tendered the oath refused to subscribe to it and was fined $£ 200$ for his recalcitrance. ${ }^{83}$ Colm Lennon observed that, 'Refusals of the oath of supremacy by municipal officials are not recorded for the reason that the oath was not tendered to them'. ${ }^{84}$ When, in 1585 , Deputy Perrot tried to insist that justices of the peace and other law officials in the Pale take the oath, ${ }^{85}$ the queen wrote to Perrot personally to command him to desist, 'especially in matter of oath and religion, which was charged you not to meddle in'. 86

The inability of the crown to insist that the ruling elites subscribe to the oath of supremacy was extremely significant. Without their cooperation, Shagan termed it 'collaboration', conformity to the Elizabethan Reformation could not be imposed in the face of popular dissent in the localities. ${ }^{87}$ Bishop Hugh Brady complained in a letter in March 1564 that the local law enforcement officials 'are not only sworn enemies of the truth but also for lack of due execution of the law the out-throwers of the country' ${ }^{88}$ The queen's commissioners confirmed Brady's lament. ${ }^{89}$ When directed to identify individual Catholic dissidents as was normally done in England they could not do so because dissent was so general. Indeed, the scale of non-conformity was such that they decided that it was best to "meddle not with the simple multitude' but to target one or two prominent Catholic dissidents in each shire to serve as examples pour encourager les autres. In 1570 Brady was still complaining of the local officials that, 'So are they, for the most part, nay, I might say all, thwarters and hinderers of matters that should tend to the Reformation of religion'. 90

The Irish Ecclesiastical High Commission focused its attentions on the Pale. ${ }^{91}$ The projection of the Reformation into Munster and Connacht in tandem with the assertion of royal authority in those provinces from 1567 was soon followed by rebellions across the south and west of Ireland in which religious dissent and political grievances were intertwined. ${ }^{92}$ A crackdown on Catholicism in the Pale from 1577 immediately preceded the Baltinglass rebellion, led by a young Catholic nobleman who had been a prominent victim

83 Colm Lennon, The lords of Dublin in the age of Reformation (Dublin, 1989), p. 134.

84 Ibid.

85 R. D. Edwards, Church and state in Tudor Ireland: a history of penal laws against Irish Catholics (Dublin, 1935), pp 270-1; Victor Treadwell, 'Sir John Perrot and the Irish parliament of 1585-6' in R.I.A. Proc., vol. 85, sect. C (1985), p. 274.

${ }_{86}$ Treadwell, 'Irish parliament of 1585-6', pp 292-3.

87 Ethan A. Shagan, Popular politics and the English Reformation (Cambridge, 2003), pp 10,17, 306. The disappearance of the office of churchwarden denied the crown a key institution for enforcing religious conformity.

${ }^{88}$ Shirley, Original letters, p. 135, letter liii.

89 Ibid., pp 139-41, letter liv.

90 W. M. Brady, State papers concerning the Irish Church (London, 1868), pp 8-9, letter v.

91 James Murray, 'The Tudor diocese of Dublin: episcopal government, ecclesiastical politics and the enforcement of the Reformation, c.1534-1590' (Ph.D. thesis, Trinity College, Dublin, 1997), p. 254.

92 Jefferies, Irish church, pp 166-8, 180-5. 
of that crackdown. ${ }^{93}$ Recent research has revealed that the rebellion enjoyed widespread support, most but not all of it tacit, from landholders throughout the Pale, to the very highest levels of society, with Jesuit priests playing a vital role in swearing men to either join in the rebellion, or at least not stand in its way. ${ }^{94}$ Deputy Grey was warned against 'being strict in dealing with religion' for fear of fanning the flames of rebellion. ${ }^{95}$ Adam Loftus, Elizabethan archbishop of Dublin, tried to create the impression that Grey's successor, Perrot, was responsible for allowing recusancy to become established in the Pale circa $1585 .{ }^{96}$ In fact, however, Perrot was directed to cease his earnest efforts to enforce conformity to the queen's religious settlement by Elizabeth herself. She wrote to him directly that, 'I marvel, you lack so much discretion in these dangerous days to touch that point of religion'. ${ }^{97}$ Elizabeth had no illusions about the destabilising effects of an insistence on conformity to her religious settlement in Ireland.

In March 1564 Elizabeth's commissioners for Ireland informed her that the only Protestant preachers in all of Ireland were Loftus, archbishop of Armagh, Brady, bishop of Meath, and a vicar visiting from Greenwich, 'one Beard, a preacher who seems honest and preaches well'. ${ }^{98}$ It is quite remarkable that almost six years into her reign, Elizabeth's Reformation was being promoted by preaching among the approximately 2,500 parishes in Ireland by only two Protestant bishops and a vicar visiting briefly from London. For anyone trying to explain why the Reformation failed in Ireland, the absence of Protestant preachers from the start of Elizabeth's reign must surely count as a significant factor.

The lack of preachers continued to stymie the progress of Elizabeth's Reformation in Ireland throughout her reign. In 1565 Sidney, immediately prior to his appointment as the viceroy in Ireland, ventured his opinion that the only way to promote the Reformation was 'by sending learned pastors from hence [England] and by giving them competent livings there [in Ireland]'. ${ }^{99}$ He saw no prospect of being able to recruit Irish Reformation pastors. Subsequent developments confirmed his pessimism and in 1576 he asked that a search be conducted in England's universities for anyone who could speak Irish and would willingly serve as a minister in Ireland and, if there were none or not enough, he suggested that the Scottish regent be approached to help remedy the deficiency. ${ }^{100} \mathrm{He}$ hoped for 'ten or twelve at the least', a request which reflected the sheer lack of preachers in Ireland almost eighteen years into Elizabeth's reign. Eight years later, in 1584, the prebendaries

93 Ibid., pp 205-7, 214-19.

94 Ibid., pp 215-16.

95 Brady (ed.), State papers concerning Ir. Ch., pp 43-4, letter xxix.

96 Adam Loftus to Burghley, 22 Sept. 1590 (T.N.A., SP 63/94/37); Jefferies, Irish church, pp 234-6.

97 Treadwell, 'Irish parliament of 1585-6', pp 292-3.

98 Shirley, Original letters, pp 140-1, letter liv.

99 Ibid., p. 210, letter lxxv.

100 Brady (ed.), State papers concerning Ir. Ch., pp 17-18, letter xi. 
of St Patrick's Cathedral, Dublin, declared that there was 'not one in that land which can or will preach the gospel, four bishops and the prebendaries of St Patrick's only excepted'. ${ }^{101}$ An Irish Protestant in July 1600 declared that in all of Ireland there were still only twenty-four preachers, eight of whom were Irishborn and the rest English, of whom fourteen were English army chaplains. ${ }^{102}$ Without preachers the Elizabethan Church of Ireland could not mount a convincing campaign for the hearts and souls of people, even in the Pale.

Steven Ellis broke new ground by revealing the existence of the Irish Valor ecclesiasticus and teasing out its implications for the Reformation. ${ }^{103} \mathrm{He}$ highlighted the poverty of the Irish church and argued that without the resources necessary to support a plentiful and qualified preaching ministry the Church of Ireland's prospects were 'bleak indeed'. ${ }^{104}$ However, he did not see the economic problems of the Irish church by themselves as determining the outcome of the Reformation. He observed that the poverty of the ecclesiastical endowment, together with the inadequacies of government control, allowed the local elites considerable influence on the course of the Reformation. ${ }^{105}$ One might observe that there were actually more remunerative benefices available in Ireland than there were Protestant ministers to appoint to them: the basic problem was the sheer absence of an Irish Protestant community from which Protestant clergymen could be recruited, whatever the value of Irish benefices. Failure begat failure.

Comparisons with the Gaelic-speaking diocese of Argyll in Scotland suggest that the absence of a local university was a more significant factor in influencing the course of the Reformation. Despite the low value of its benefices, more than a third of Argyll's known clergy were graduates on the eve of the Reformation, and higher education may have predisposed some portion of them to engage with Reformation theology. ${ }^{106}$ By contrast, graduates were very rare in Ireland. ${ }^{107}$ It is conceivable that the foundation of an Irish university early in Elizabeth's reign might have generated a body of Irish graduates from whom a native Protestant ministry might have been recruited. Elizabeth took possession of the Hospital of Kilmainham at the start of her reign and the tithes that had been impropriated to religious houses, and she might have invested them in the foundation of a university in Ireland. However, that raises the question of how such an institution could have been staffed with suitably-qualified Protestants at such an early date: none could be found in Ireland, and it proved strikingly difficult to find English clergymen of any high calibre who were willing to settle in Ireland.

Nonetheless, physical access to a university ought not, by itself, to be considered a critical reason for the failure of the Reformation in Ireland. Archbishop Loftus, writing from Dublin in March 1585, pointed out that

101 Prebendaries of St Patrick's Cathedral, Dublin, to the lords of the council in England, Dec. 1584 (T.N.A., SP 63/113/58); Brady (ed.), State papers concerning Ir. Ch., p. 94, letter lxv.

102 Jefferies, Irish church, p. 246.

103 Ellis, 'Economic problems', pp 239-65.

104 Ibid., p. 257.

105 Ibid., p. 264.

106 Iain G. MacDonald, Clerics and clansmen: the diocese of Argyll between the twelfth and sixteenth centuries (Leiden, 2013), p. 232.

107 Jefferies, Priests and prelates of Armagh, p. 39; idem, Irish church, p. 30. 
'Oxford and Cambridge are not far off'. ${ }^{108}$ More could have been done to encourage young Irish men to study in England's universities. ${ }^{109}$ However, neither the English crown nor the Elizabethan church establishment made systematic investment in clerical education or training in Ireland. In the absence of Protestant clergymen, the Elizabethan church authorities had to retain priests who were Catholic by background, education, training and disposition but willing to conform to some degree to earn a living, or else appoint men of very poor quality such as those of whom Lord Chancellor Weston, head of the Irish Ecclesiastical High Commission, writing in April 1568, complained, 'be so void of knowledge of God and his will that they know not his commandments'. ${ }^{110}$ Andrew Trollope, an English observer who made a special point of investigating the state of the Irish church, writing in October 1587 , observed that a great many parishes were served by curates who 'will not be accounted ministers but priests. ... And when they must of necessity go to church they carry with them a book in Latin of the Common Prayer set forth and allowed by her majesty, but they read little or nothing of it, ... but they tell the people a tale of Our Lady or St Patrick or some other saint'. ${ }^{111}$ The prebendaries of St Patrick's Cathedral, Dublin, wrote of curates subsisting on stipends of only $£ 2$ or $£ 3$ per annum and travelling about 'like a lackey to three or four churches in a morning $\ldots$ and there once a week reads them only a Gospel in Latin, and so away'. 112 Sidney reported in 1577 that, 'All these live upon the bare altarages ... and were wont to live upon the gain of Masses, dirges, shrivings and such like trumpery godly abolished by your majesty'. ${ }^{113}$ Edmund Spenser wrote in 1596 that, 'They neither read scriptures, nor preach to the people, nor administer the communion, but baptism they do, for they christen after the Popish fashion, only they take the tithes and offerings.' ${ }^{114}$

For historians struggling to explain why the Reformation failed in Ireland the absence of Protestant preachers, and the employment of many clergy who simply read an extract from the Latin edition of the Book of Common Prayer or a gospel in Latin for church services, must surely form a key component of their overall explanation. However, that does not mean that the provision of preachers would automatically have resulted in mass conversions to Protestantism. Barnaby Rich, writing in 1589, remarked that in Dublin, Drogheda and Waterford, 'the word of God has been for many years most plentifully preached', to no avail. ${ }^{115}$ The earnest sermons of Bishop Matthew Sheyne of Cork and Cloyne, backed up by an English garrison, failed to engender a community of Protestants in Cork. ${ }^{116}$ In Galway, an English

\footnotetext{
108 Brady (ed.), State papers concerning Ir. Ch., p. 95, letter lxvi.

109 Jefferies, Irish church, pp 280-1.

110 Lord Chancellor Weston to Cecil, 2 Apr. 1568 (T.N.A., SP 63/24/2).

111 Brady (ed.), State papers concerning Ir. Ch., pp 117-20, letter lxxxvii.

112 Prebendaries of St Patrick's Cathedral, Dublin, to the lords of the council in England, Dec. 1584 (T.N.A., SP 63/113/58).

113 Brady (ed.), State papers concerning Ir. Ch., p. 16, letter xi.

114 Edmund Spenser, A view of the present state of Ireland in Sir James Ware (ed.). Ancient Irish histories (repr., 2 vols, Dublin, 1809), i, 142.

115 Book drawn by Barnaby Rich and delivered to the Lord Deputy Fitzwilliam, 1589 (T.N.A., SP 63/144/35); Canny, 'Why the Reformation failed', p. 433.

116 Henry A. Jefferies, 'Tudor Reformations in Cork' in Salvador Ryan and Clodagh Tait (eds), Religion and politics in urban Ireland, c.1500- c.1750 (Dublin, 2016), pp 51-69.
} 
preacher named Walton, who was also backed up by the military muscle of a provincial council, tried hard but ultimately failed to create an enduring community of Protestants. ${ }^{117}$

\section{VI}

The fact that the Reformation won remarkably few converts in Elizabethan Ireland was no guarantee that Catholicism would survive. The geographically circumscribed nature and the chronologically extended timeframe of the extension of Elizabeth's Reformation across Ireland helped to facilitate the Catholic church's survival over much of Ireland. As late as the 1590s the bishop of Derry, a papal legate and the vice-primate of all Ireland, was able to progress across much of the northern province much as he might have done in Mary's reign. ${ }^{118}$ Archbishop Magrath complained in 1590 that there were sixteen monasteries and friaries in Ulster 'wherein the monks and friars remain, using their habit and service as in Rome itself is used ... The clergy there have even changed the time according to the pope's new invention [i.e. the Gregorian calendar]'. ${ }^{119}$ The eve-of-plantation survey of the church in Ulster conducted by George Montgomery, the first Protestant bishop of Clogher, Derry and Raphoe, revealed that the Catholic church still had resident priests in parishes and tenants on episcopal estates into the first decade of the seventeenth century. ${ }^{120}$ The same was true in other areas beyond the effective reach of the English crown. Nonetheless, the survival of the Catholic church would depend on its ability to create and sustain new structures in place of those of the medieval institution as it was progressively Protestantised and Anglicised. ${ }^{121}$

Archbishop Loftus' survey of 1565 suggests that the provision of Catholic services was so general in the Pale that it must have been co-ordinated. Loftus identified William Walsh, the Marian bishop of Meath, as the key figure galvanising Catholic opposition to Elizabeth's Reformation. ${ }^{122}$ Loftus complained that he was a man 'of great credit amongst his countrymen and upon whom (touching causes of religion) they wholly depend'. ${ }^{23}$ Also significant was David Wolfe, a former dean of Limerick who joined the Society of Jesus in response to the advent of the Edwardian Reformation in his native city. ${ }^{124}$ Wolfe was appointed as a papal commissary in $1560 .{ }^{125} \mathrm{He}$ based

117 Nicholas Canny, 'Galway: from the Reformation to the penal laws' in Diarmuid Ó Cearbhaill (ed.), Galway: town and gown, 1484-1984 (Dublin, 1984), pp 12-18.

118 Note [by the archbishop of Cashel], 17 Dec. 1590 (T.N.A., SP 63/156/12); Jefferies, Irish church, p. 251.

119 Note [by the archbishop of Cashel], 17 Dec. 1590 (T.N.A., SP 63/156/12); Jefferies, Irish church, p. 251.

${ }^{120}$ Henry A. Jefferies, 'Derry diocese on the eve of the plantation' in Gerard O'Brien (ed.), Derry and Londonderry: history and society (Dublin, 1997), pp 175-204.

${ }_{121}$ Christopher Haigh, Reformation and resistance in Tudor Lancashire (Cambridge, 1975), pp 264-9, 278.

122 Shirley, Original letters, pp 219-20, letter lxxvii.

123 Ibid.

124 Thomas J. Morrissey, 'Wolfe, David (1528-1578/9)' in Oxford D. N.B.; Jefferies, Irish church, pp 145-6.

125 P. F. Moran, History of the Catholic archbishops of Dublin since the Reformation (Dublin, 1864), pp 78-9; Morrissey, 'Wolfe, David'. 
himself in Limerick, supported by its bishop, Hugh Lacey, but he operated throughout Ireland. He knew the lords and gentlemen of Meath, for example, 'not only personally', but also 'their very frame of mind' and reported that there was only one 'heretic' among them all. ${ }^{126}$ Wolfe was instrumental in having a number of Catholic bishops appointed in Ireland, three of whom attended the final session of the Council of Trent in $1562 .{ }^{127}$ On their return to Ireland there is some fragmentary evidence to show that those bishops strove to give effect to the decrees of Trent, though the process was protracted in the face of hostility from the English crown. ${ }^{128}$

Seminary-trained priests were to be a key element in the CounterReformation in Ireland, as elsewhere. In the early 1560 s it came to the attention of the crown's administration in Dublin that Wolfe's deputy in Leinster, Thady Newman, was directly involved, physically and financially, in shipping priests and aspirant priests, of both Gaelic Irish and English descent, to Catholic colleges overseas. Memoranda among the Irish state papers in August 1564 reveal the existence of some kind of network supporting such scholars: they point to the critical role of families in sponsoring clerical students in their studies at Louvain and Paris, and also the role of some clergymen as sponsors. ${ }^{129}$

Colm Lennon uncovered a network of schools run by Catholic priests in Dublin city and county from the earliest years of Elizabeth's reign, and he speculated that the first generation of Jesuits and seminary priests who spearheaded the Counter-Reformation in Dublin had graduated from academies run by priest-teachers. ${ }^{130}$ Dr Peter White operated an academy in Kilkenny that combined high quality teaching with zealous promotion of the Catholic faith. ${ }^{131}$ White's academy has been credited as 'the single, most positive and most effective incident responsible for the failure of the Reformation in Waterford city'. ${ }^{132}$ Limerick and its hinterland was home to a series of schools operated by, among others, Thomas Leverous, the Marian bishop of Kildare, Richard Creagh and a number of Jesuits. ${ }^{133}$ The significance of the priestteachers and chaplains cannot be overstated. They gave the Catholic religion a resilience that it would not otherwise have been able to maintain, and helped to ensure that the generations who reached maturity in Ireland during Elizabeth's reign were, overwhelmingly, Catholic. ${ }^{134}$ In his study of the Reformation in Lancashire Christopher Haigh found that the Catholic missionary priests who returned to England from Catholic colleges on mainland Europe made a difference in galvanising Catholicism in the shire after 1578, but that recusancy in the county was not created by them. ${ }^{135} \mathrm{He}$ commented that: 'The seminarians

126 Moran, Catholic archbishops of Dublin, pp 78-9; Morrissey, 'Wolfe, David'.

127 Ronan, Reformation in Ireland, p. 77.

128 Jefferies, Irish church, p. 147.

129 Ronan, Reformation in Ireland, pp 113-14; Jefferies, Irish church, pp 149-50.

130 Lennon, Lords of Dublin, p. 143.

131 Colm Lennon, Richard Stanihurst: the Dubliner, 1547-1618 (Dublin, 1981), pp 24-6.

132 Niall Byrne, 'Reformation in Tudor Waterford, 1547-1603' (M.A. thesis, University College Cork, 1998), p. 31.

133 Jefferies, Irish church, p. 197.

134 Ibid., p. 189.

135 Haigh, Reformation and resistance, pp 267, 269. 
could build upon existing allegiances and did not have to build a whole new Catholic community.' ${ }^{136}$ The same was true in Ireland. Recusancy was largely the fruit of the decision taken by so many of the elites in the 1560s and 1570 s to employ Catholic priests as chaplains and tutors and ensure that their children received an unambiguously Catholic education.

Clodagh Tait interpreted the will of Sir Thomas Cusack, a former lord chancellor of Ireland, as indicating that in his part of County Meath in 1571 Catholic services were going on, seemingly as normal, in the local churches'. ${ }^{137}$ Bishop Brady complained in May 1577 that, 'Masses be rife, little less than openly said'. ${ }^{138}$ In April 1577 Lord Justice Drury reported that in Waterford, 'Masses infinite have they in their churches every morning, without any fear. I have spied them, for I chanced to arrive last Sunday at five o'clock in the morning and saw them resort out of the churches by heaps.' ${ }^{139}$ Marmaduke Middleton, Elizabethan bishop of Waterford and Lismore, wrote in 1580 of, 'Massing in every corner. ... Rome-runners and friars maintained amongst them. Public wearing of beads and praying upon the same. Worshipping of images and setting them openly in their street doors with ornaments and deckings. Ringing of bells and praying for the dead, and dressing their graves diverse times in the year with flower pots and wax candles'. ${ }^{140}$ That kind of ostentatious display of Catholic commitment may not have been possible in Dublin because of the operation there of the Irish Ecclesiastical High Commission, yet in May 1579 Secretary Waterhouse wrote of 'the whole inhabitants, being in effect all noted to be obstinate Papists' ${ }^{141}$ However, the survival of the Catholic church was by no means assured. The initial advantages it enjoyed - the retention of Catholic priests in their cures even in the Pale, and the crown's inability to insist that the population attend Elizabethan instead of Catholic church services - were diminished over time as Catholic priests died and Elizabethan bishops were appointed to more and more dioceses. There was a growing challenge to maintain a Catholic ministry in the parishes. Edmund Tanner, a former Jesuit, returned to Ireland in June 1576 because he had been told that although there were not 100 Irish 'heretics' in Ireland the people lacked religious instruction. $^{142}$

Before the advent of seminary priests in substantial numbers in Ireland mendicant friars played a significant role in sustaining Catholic commitment. Their primary contribution to the religious struggle was the provision of committed and effective preachers working across extensive areas, who could appeal directly to receptive audiences, and operate at a fraction of the cost of educating, training and waging their counterparts in the Elizabethan Church of Ireland. Bishop Brady complained in 1577 that friars were operating

136 Ibid., p. 278.

137 Clodagh Tait, "As legacie upon my soul": the wills of the Irish Catholic community, c.1550-c.1660' in Robert Armstrong and Tadhg Ó hAnnracháin (eds), Community in early modern Ireland (Dublin, 2006), p. 188.

138 Hugh Brady to Henry Sidney, 12 May 1577 (T.N.A., SP 63/58/16).

139 Brady (ed.), State papers concerning Ir. Ch., pp 23-4, letter xv.

140 Ibid., pp 39-42, letter xxv.

141 Edward Waterhouse to Walsingham, 31 May 1579 (T.N.A., SP 63/66/66).

142 Evelyn Bolster, A history of the diocese of Cork: from the Reformation to the penal era (Cork, 1982), p. 74. 
'openly' in the Pale. ${ }^{143}$ The increased references to friars in the 1570 s may have reflected a revival of some kind in the fortunes of mendicant communities following a mid-century nadir, after the Henrician dissolution and a wider collapse in confidence that affected houses beyond the crown's reach. ${ }^{144}$ By the 1570 s there is compelling evidence of friars acting as agents of the CounterReformation, with close links to Rome, France and Spain, and a readiness to see the implications of developments in France and Spain for Ireland. ${ }^{145}$ The Franciscans convened a general council in Galway in October 1572, traversed the country in groups of ten to twenty, and planned future conventions in Ulster and in Munster. Deputy Fitzwilliam commented that it was 'no new thing to have friars gad up and down in Ireland'. ${ }^{146}$

In 1577 Irish clergymen in Catholic colleges on mainland Europe were directed to return to Ireland to support the Catholic cause and to prepare the way for a rebellion planned against Elizabeth. ${ }^{147}$ Sir William Drury, president of Munster, reported on the dramatic impact of four such men in galvanising recusancy in the south-east of Ireland: one of them, John White, was 'worshipped like a god between Kilkenny, Waterford and Clonmel'. ${ }^{148}$ Jesuits and other clergy canvassed widely for support for rebellion in the Pale: the scale of their efforts were exposed in the aftermath of the Baltinglass rebellion and the so-called Nugent conspiracy of $1580-1 .^{149}$ The most important of the Counter-Reformation clergy to return to Ireland during the Desmond rebellion was Dr Dermot Creagh, who was a Jesuit, Catholic bishop of Cork and Cloyne and a papal legate. ${ }^{150}$ Creagh remained an ardent advocate of rebellion against the heretical English long after the Desmond rebellion fizzled out, but his primary achievement was in the reorganisation of the Catholic church across the south of Ireland. He marshalled a number of Counter-Reformation clergy, whose surnames indicate that they were drawn from the propertied classes of the south, men with Irish surnames as well as Old English, into a corps of clerical shock troops who bolstered the efforts of local clergymen to keep the population loyal to Rome. Archbishop Magrath described one of them, Tadhg O'Sullivan, as 'an earnest preacher' who was 'preaching from house to house in Waterford, Clonmel and Fethard and in the country about those towns' ${ }^{151}$ By the 1590 s English officials were complaining constantly about 'swarms' of seminary priests active across southern Ireland. ${ }^{152}$ However, though their numbers had certainly grown over the course of Elizabeth's reign it seems that the tremendous energy shown by men like Tadhg O'Sullivan gave an exaggerated impression of their true number.

Creagh organised a mass withdrawal of priests from benefices in the Elizabethan Church of Ireland, and established a parallel Catholic parish

143 Hugh Brady to Henry Sidney, 12 May 1577 (T.N.A., SP 63/58/16).

144 T. S. Flynn, The Dominicans in Ireland, 1534-1641 (Dublin, 1993), pp 44-71.

145 Jefferies, Irish church, pp 178-80.

146 Ibid., p. 179.

147 Ronan, Reformation in Ireland, p. 580.

148 Brady (ed.), State papers concerning Ir. Ch., pp 22-3, letter xv.

149 Jefferies, Irish church, pp 215-16.

150 Ibid., pp 252-4.

151 Meiler Magrath to Burghley, 30 May 1592 (T.N.A., SP 63/164/47).

152 Jefferies, Irish church, pp 246, 248, 256-7. 
system on a sustainable footing. ${ }^{153}$ The willingness of people to pay for Catholic rites was of critical importance for the survival of the Catholic church in the wake of its displacement from parish benefices and the loss of the tithes and real estates it had held. Creagh insisted that Catholics swear an oath acknowledging the pope's spiritual and temporal pretensions before being allowed access to Catholic sacraments: 'their names are written presently in a book which is the register written by the said Dr Creagh's own hand and termed the "Book of Life", and no Irishman can have life everlasting unless his name be written in the said book'. ${ }^{154}$ Sir John Dowdall, commander of the English garrison at Duncannon, near Waterford, observed that 'every town is established with sundry schools ... and each school overseen by a Jesuit'. ${ }^{155}$ Barnaby Rich, a seasoned observer of Irish affairs, informed Sir Robert Cecil in 1591 that, 'Friars, Jesuits, seminaries [sic] and Massing priests and such others have free and common recourse throughout the diocese[s] and every city, town and province is so plentifully replenished with them that there is neither nobleman nor gentleman but he has some of them in his house and keeps them openly without controlment'. ${ }^{156}$ Edmund Spenser was impressed by the 'zeal' of the Catholic clergy who returned from overseas knowing that 'peril of death awaits them and no reward or riches to be found only to draw the people unto the Church of Rome', whereas he complained that some of the 'idle ministers' of the established church could not be drawn from their 'warm nests' for love of God or money. ${ }^{157}$

The evidence of contemporaries across the denominational divide makes it clear that Elizabeth's Reformation in Ireland had failed comprehensively and absolutely before the close of her reign. Edmund Tanner, a former Jesuit, observed in 1576 that there were 'not 100 heretics' in Ireland. ${ }^{158}$ John Long, Elizabethan archbishop of Armagh and primate of all Ireland, wrote in July 1585 that, 'It is a hard thing to be thought of that the land [of Ireland] is not able to afford, of the birth of the land, forty Christians which have the taste of the true service of God'. ${ }^{159}$ In July 1600 an Irish Protestant reckoned that there were hardly 120 Irish-born Protestants in all of Ireland. ${ }^{160}$

The fundamental answer to the question of why the Reformation failed in Ireland is that it did not secure indigenous support. Without it Elizabeth's Reformation could neither be enforced nor propagated effectively in the parishes. The elites could not be forced to subscribe to the oath of supremacy, nor to attend Protestant church services regularly. Occasional bouts of attendance under duress were never likely to yield fruit in the absence of a committed Protestant ministry. One suspects that it only served to alienate the

153 Ibid., pp 252-8, 260.

154 Meiler Magrath to Burghley, 30 May 1592 (T.N.A., SP 63/164/47).

155 John Dowdall to Burghley, 9 Mar. 1596 (T.N.A., SP 63/187/19).

156 Barnaby Rich to Robert Cecil, Dec. 1599 (T.N.A., SP 63/206/119).

157 Spenser, View, pp 254-5.

158 Bolster, Diocese of Cork, p. 74.

159 Brady (ed.), State papers concerning Ir. Ch., p. 98, letter lxix.

160 Intelligences for her majesty's services, 3 July 1600 (Cal. S.P. Ire., 1600, p. 295). 
local population: when the chief men of Waterford were forced to attend a Protestant service it was reported that they 'walk round like mill horses, chopping, changing, making merchandise, so that they in the choir [i.e. around the altar] cannot hear a word'. ${ }^{161}$ The absolute futility of the exercise hardly needs to be spelled out.

Elizabeth failed to invest enough energy and resources to overcome the general opposition roused by her religious programme in Ireland, and unwittingly she allowed the people to decide their own religious destinies. From the very start of her reign the crown's officials who were charged with imposing conformity to the Elizabethan religious settlement in Ireland were unanimous in pointing to Catholic opposition to explain their lack of progress. No contemporary commentator, neither Catholic nor Protestant, English nor Irish, saw any prospect of a Reformation breakthrough. In September 1590 , when considering why the Reformation failed so comprehensively, Archbishop Loftus wrote that 'there has been in these people a general disposition to Popery, as a thing wherein they were nursled even from the cradle'. ${ }^{162}$ One might quibble with Loftus' judgement, based though it was on three decades of experience of religious controversy in Ireland, but the evidence certainly suggests that historians of the Tudor Reformations in Ireland ought to take due account of religious considerations when addressing the question of why the Reformation failed in Ireland.

It is clear that, by striking contrast with England and Scotland, Ireland experienced a 'Reformation without reformers' in Elizabeth's reign, and that was a key reason for its failure. Yet that suggests that the roots of failure must be traced earlier in the sixteenth century. Reformation theology first penetrated Britain through seaports trading with the German-speaking heartlands of the Reformation, through university students who studied either in England or Scotland or in northern Europe, or through print. Its early adherents formed the basis of communities of Evangelicals that were to transform the English and Scots into Protestants. ${ }^{163}$ On the other hand, Irish trade with the north of mainland Europe was limited and mostly indirect. Ireland had no university, and very few graduates. There is little or no evidence of controversial printed books or pamphlets circulating in Ireland in the first half of the sixteenth century. There are, then, mundane contributory reasons why Reformation theology made so little impact in Ireland before Elizabeth's reign. Bishop Bale's account of his short ministry in Kilkenny in 1553 suggests that some people in Ireland, especially among the young men of the Anglophone elites, might have responded positively to the Reformation if it had been presented to them effectively - but Bale was unique and one must be cautious in trusting his account because of the didactic purpose of his Vocacyon.

In any case, the central fact remains that there were virtually no Irish Protestants in 1560 to transform Elizabeth's religious legislation into a true Reformation. Without indigenous support, and against general and deeply-entrenched hostility, the failure of the Elizabethan Reformation in

161 Brady (ed.), State papers concerning Ir. Ch., p. 99, letter 1xx.

162 Adam Loftus to Burghley, 22 Sept. 1590 (T.N.A., SP 63/94/37); Brady, 'Conservative subversives', p. 11.

163 Two of the best surveys of this subject are Peter Marshall and Alec Ryrie (eds), The beginnings of English Protestantism (Cambridge, 2002) and Alec Ryrie, The origins of the Scottish Reformation (Manchester, 2006). 
Ireland was probable from the start, but it was not irrevocable, at least until the 1580s. Across England and Scotland the Catholic church atrophied after 1560 as priests were displaced from parish cures and died, and Catholicism withered to a remnant of its former self, while Protestantism triumphed in an overwhelming fashion. Only when the Catholic church in Ireland was re-organised on a sustainable footing as a disestablished 'people's church' from the 1580s, and infused with the confidence inspired by the CounterReformation, can it be stated that the Reformation had failed in Ireland definitively. 